\title{
FORMULASI MODEL PERMUTASI SIKLIS DENGAN OBJEK MULTINOMIAL
}

\author{
Sukma Adi Perdana \\ Ska88perdana@gmail.com \\ Pendidikan Matematika - FKIP Universitas Maritim Raja Ali Haji \\ 2016
}

\begin{abstract}
Abstrak
Penelitian ini bertujuan membangun model matematika untuk menghitung jumlah susunan objek dari permutasi siklis yang memiliki objek multinomial. Model yang dibangun dibatasi untuk permutasi siklis yang memiliki objek multinomial dengan minimal ada satu jenis objek beranggotakan tunggal. Pemodelan dilakukan berdasarkan struktur matematika dari permutasi siklis dan permutasi multinomial. Model permutasi siklis yang memiliki objek multinomial telah dirumuskan, yaitu $\frac{(n-1) !}{n_{1} ! n_{2} ! \ldots n_{r} !}$. Pembuktian model telah dilakukan melalui validasi struktur serta validasi hasil yang dilakukan dengan cara membandingkan hasil perhitungan model dan hasil pencacahan. Teorema tentang permutasi siklis dengan objek multinomial juga telah dibangun.
\end{abstract}

Kata kunci: pemodelan, permutasi siklis, permutasi multinomial.

This study aims at constructing mathematical model to count the number of arrangement of objects form cyclical permutation that has multinomial objects. The model constructed is limited to cyclical permutation that has multinomial object in which at least one kind of object having single cardinality is contained within. Modelling is undertaken based on mathematical structure of cyclical permutation and multinomial permutation. Cyclical permutation model having multinomial object has been formulated as $\frac{(n-1) !}{n_{1} ! n_{2} ! \ldots . n_{r} !}$. The proof of the model has been undertaken by validating structure and validating the outcome which was conducted by comparing counting result of model and counting result manually. The theorem of cyclical permutation with multinomial object has also been developed.

Keywords: modelling, cyclical permutation, multinomial permutation

\section{Pendahuluan}

Dalam kehidupan sehari-hari banyak ditemukan kasus yang berhubungan dengan penyusunan objek. Misalkan terdapat beberapa objek yang berbeda dimana beberapa objek tersebut akan dibentuk suatu susunan objek, contohnya seperti nomor telepon, susunan lampu hias, dan susunan huruf. Susunan objek berbeda dengan memperhatikan urutannya tersebut dinamakan permutasi, dimana dapat ditentukan jumlah permutasi atau susunan yang dapat terjadi dari beberapa objek tersebut dengan persamaan yang telah dirumuskan. Pada kenyataannya, 
penyusunan objek tersebut tidak selalu lurus dan tidak semua objek selalu berbeda.

Kondisi permutasi dimana susunan objeknya tidak lurus akan tetapi membentuk sebuah lingkaran disebut dengan permutasi siklis. Menurut Munir (2005), permutasi siklis adalah penyusunan objek-objek yang mengelilingi sebuah lingkaran atau daerah tertutup sederhana. Contoh dari permutasi siklis pada kehidupan nyata adalah susunan anggota rapat yang mengelilingi sebuah meja bundar. Adapun untuk mengetahui jumlah permutasi siklis dapat diketahui dengan persamaan yang telah dirumuskan.

Keadaan penyusunan objek dimana tidak semua objek berbeda jenis disebut dengan permutasi multinomial. Permutasi multinomial juga dapat diartikan sebagai permutasi dengan kondisi terdapat beberapa objek yang sejenis. Contoh dari permutasi multinomial pada kehidupan nyata adalah banyak cara membagikan delapan buku yang berbeda kepada tiga orang, dimana orang pertama mendapat empat buku, orang kedua 2 buku, dan orang ketiga 2 buku. Adapun untuk mengetahui jumlah permutasi multinomial dapat diketahui dengan persamaan yang telah dirumuskan. Pada penyusunan beberapa objek secara melingkar, jumlah penyusunan objek tersebut dapat diketahui dengan konsep permutasi siklis.

Pada kasus tertentu di kejadian nyata terdapat juga kondisi dimana objek-objek yang akan disusun melingkar memiliki beberapa objek sejenis. Pada kejadian beberapa objek yang sejenis ini bukanlah murni permutasi siklis, melainkan permutasi siklis yang memiliki beberapa objek yang berwarna sama atau bisa disebut permutasi siklis dengan objek multinomial. Pada kasus dimana dilakukan penggabungan kondisi dari permutasi siklis dan permutasi multinomial ingin diketahui banyaknya jumlah susunan objek yang terjadi. permutasi yang demikian dikatakan sebagai permutasi siklis dengan objek multinomial. Pada kasus tersebut untuk mengetahui jumlah susunan objek yang terjadi dapat diketahui dengan melakukan pencacahan karena belum ditemukan persamaan untuk menghitung kondisi permutasi seperti ini. Pencacahan dilakukan dengan menghitung satu persatu anggota kejadian yang terjadi dari penyusunan objek secara melingkar dimana beberapa objek berwarna sama atau sejenis. Cara berhitung mencacah seperti ini membutuhkan waktu yang lama dan untuk menentukan anggota kejadian sangat menyulitkan karena membutuhkan kejelian dalam melihat apakah sebuah kejadian telah dihitung atau belum. Dikarenakan proses yang sangat rumit tersebut sehingga sangat dibutuhkan sebuah model matematika yang dapat membantu untuk menghitung jumlah susunan objek yang dapat terjadi dari kondisi permutasi siklis dengan objek multinomial.

\section{Kajian Literatur}

Kombinatorial adalah ilmu yang mempelajari pengaturan objek-objek. Solusi yang ingin diperoleh dengan kombinatorial ini adalah jumlah cara pengaturan objek-objek tertentu di dalam himpunannya (Munir, 2005).

\subsection{Permutasi}

\section{Definisi 1}

Permutasi $r$ dari $n$ unsur yang berbeda $x_{1}, x_{2}, \ldots$ , $x_{n}$ adalah pengurutan dari sub-himpunan dengan $r$ anggota dari himpunan $\left\{x_{1}, x_{2} \ldots, x_{n}\right\}$. Banyaknya permutasi $r$ dari $n$ unsur yang berbeda dinotasikan dengan $P(n, r)$.

\section{Teorema 1}

Banyaknya permutasi $r$ dari $n$ unsur yang berbeda adalah $P(n, r)=\frac{n !}{(n-r) !}$

\section{a. Permutasi Siklis}

Misalkan ada 10 orang yang duduk pada suatu barisan fungsi yang terdiri dari 10 kursi. Menurut rumus permutasi, ada sebanyak $\mathrm{P}(10$, $10)=10$ ! Cara pengaturan tempat duduk bagi 10 orang tersebut. Sekarang, misalkan 10 orang tersebut disuruh duduk mengelilingi meja melingkar. Berapakah jumlah cara pengaturan tempat duduk bagi mereka tersebut. Satu orang dapat duduk pada tempat duduk mana saja. Sembilan orang lainnya dapat duduk dalam 
$9 \times 8 \times 7 \times 6 \times 5 \times 4 \times 3 \times 2 \times 1=9$ ! cara. Meskipun orang pertama dapat memilih tempat duduk mana saja, namun susunan tempat duduk yang dihasilkan oleh 9 orang lainnya tetap sama. Ini dinamakan permutasi melingkar yang dirumuskan pada teorema sebagai berikut (Herrhyanto \& Gantini, 2009):

\section{Teorema 2}

Jika terdapat n objek yang berbeda, maka banyak permutasi melingkar yang dapat dibentuk ada: $(n-1) !$

Pembuktian permutasi melingkar cukup sederhana yaitu, objek pertama dapat ditempatkan di mana saja pada lingkaran dengan 1 cara. Sisa $n$-1 objek lainnya dapat diatur searah jarum jam dengan $P(n-1, n-1)=(n-1)$ ! .

\section{b. Permutasi Multinomial}

Secara umum banyaknya permutasi dari objek yang mempunyai beberapa unsur sama dapat dijabarkan seperti pada teorema berikut ini (Munir,2005).

\section{Teorema 3}

Misalkan X merupakan sekelompok objek yang mempunyai $n$ unsur, dimana terdapat $n_{1}$ unsur yang sama untuk jenis $1, n_{2}$ unsur yang sama untuk jenis 2 dan seterusnya sampai $n_{r}$ unsur yang sama untuk jenis $r$. Banyaknya permutasi dari $X$ adalah $\frac{n !}{n_{1} ! n_{2} ! \ldots . n_{r} !}$.

\section{Metode Penelitian}

Penelitian ini menggunakan pendekatan empiris. Penyelidikan dilakukan dengan mencacah beberapa permutasi siklis dengan objek multinomial. Selanjutnya dilakukan perhitungan variasi hasil pencacahan. Kesimpulan dirumuskan dengan melihat pola dari banyak variasi yang muncul dengan perhitungan serta dilanjutkan dengan pemodelan persamaan dari variasi permutasi tersebut.

\section{Hasil dan Pembahasan}

Susunan objek yang melingkar dengan beberapa anggota objek memiliki jenis yang sama didefinisikan dengan permutasi siklis dengan objek multinomial. Bentuk permutasi siklis dengan objek multinomial dapat dicontohkan seperti di bawah ini.

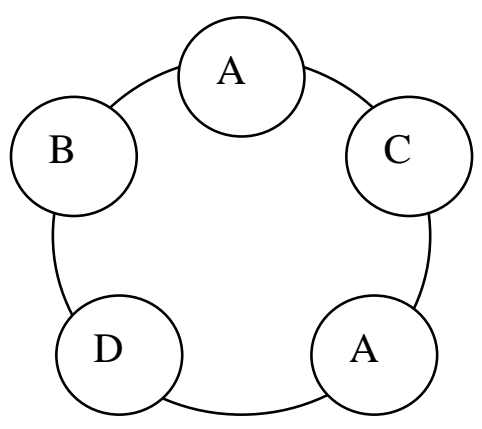

Dikarenakan permutasi siklis dengan objek multinomial merupakan gabungan dari permutasi siklis dan permutasi multinomial, maka dapat digunakan struktur pembentukan permutasi siklis dan permutasi multinomial tersebut untuk mendapatkan model permutasi siklis dengan objek multinomial. Langkah-langkah yang ditempuh untuk mendapatkan model dilalui dengan dua tahap.

Pertama, permutasi siklis dengan objek multinomial dipandang sebagai permutasi siklis. Berdasarkan tinjauan terhadap permutasi siklis maka susunan objek yang berbentuk lingkaran bisa dirumuskan modelnya dengan melihat kejadian permutasi ini menjadi kejadian permutasi biasa, yaitu dengan mengambil satu objek dari $n$ objek sebagai acuan untuk menghilangkan sifat melingkar dari permutasi siklis. Oleh karena dari $n$ objek dihilangkan satu objek maka permutasinya menjadi $(n-1)$ !.

Kedua, setelah dipandang sebagai permutasi siklis selanjutnya dianggap banyaknya objek menjadi $n$-1 buah. Dari $n$-1 objek tersebut ditetapkan banyak pengurutan yang mungkin dari objek-objek itu. Seandainya dari $n-1$ buah objek mempunyai $n_{1}$ objek identik berjenis $1, n_{2}$ objek berjenis $2, \ldots$, dan $n_{\mathrm{r}}$ objek identik berjenis $r$. Dimana $n_{1}+n_{2}+\ldots+n_{\mathrm{r}}=n-1$. Susunan posisi $n_{1}$ unsur dari jenis 1 dalam $C\left(n-1, n_{1}\right)$ cara. Setelah dilakukan penempatan jenis 1 , maka dapat ditetapkan posisi untuk $n_{2}$ unsur dari jenis 2 dalam $C\left(n-1-n_{1}, n_{2}\right)$ cara dan seterusnya sampai $n_{\mathrm{r}}$ unsur yang sama untuk jenis $r$ dalam 
$C\left(n-1-n_{1}-n_{2}-\ldots-n_{r-1}, n_{r}\right) \quad$ cara. Menurut prinsip perkalian, susunan yang mungkin adalah:

$P\left(n-1, n_{1}, n_{2}, n_{3}, \ldots, n_{r}\right)=$

$C\left(n-1, n_{1}\right) C\left(n-1-n_{1}, n_{2}\right) C\left(n-1-n_{1}-n_{2}, n_{3}\right) \ldots$

$C\left(n-1-n_{1}-n_{2}-\ldots-n_{r-1}, n_{r}\right)$

$=\frac{(n-1) !}{n_{1} !\left(n-1-n_{1}\right) !} \frac{\left(n-1-n_{1}\right) !}{n_{2} !\left(n-1-n_{1}-n_{2}\right) !} \ldots$

$\frac{\left(n-1-n_{1}-n_{2} \ldots n_{r-1}\right) !}{n_{r} ! 0 !}$

$P\left(n-1, n_{1}, n_{2}, n_{3}, \ldots, n_{r}\right)=\frac{(n-1) !}{n_{1} ! n_{2} ! \ldots . n_{r} !}(1)$

Berdasarkan kedua tinjauan di atas maka model yang dapat digunakan untuk menghitung permutasi siklis dengan objek multinomial adalah Persamaan (1).

\section{Kesimpulan}

Pada penelitian ini dihasilkan sebuah formula untuk menghitung jumlah variasi permutasi siklis dengan objek multinomial dengan minimal ada satu jenis objek beranggotakan tunggal. Formula tersebut juga telah dirumuskan dalam Persamaan (1) .

\section{Referensi}

Bona,M.2006. A Walk Through Combinatorics : An Introduction To Enumeration and Graph Theory.World Scientific.Singapore.

Budhi,WS.2003. Langkah Awal Menuju ke Olimpiade Matematika.Ricardo.Jakarta.

Herhyanto, Nar dan Tuti.G.2009. Pengantar Statistika Matematika. Yrama Widya. Bandung

Johnsonbaugh,R.1997. Matematika Diskrit. Prenhallindo. Jakarta.

Munir,R.2005. Matematika Diskrit. Penerbit Informatika. Bandung. 